\title{
Peculiarities of Discourse Organization in M.A. Bulgakov's Novel The Master and Margarita
}

\section{[Особенности коммуникативной организации дискурса в романе М.А. Булгакова «Мастер и Маргарита»]}

\author{
Anatolij A. Girutskij
}

\section{DOI: 10.18355/XL.2015.08.04.78-90}

\begin{abstract}
Резюме
Особенности коммуникативного пространства романа «Мастер и Маргарита» характеризуются столкновением двух начал: физического и метафизического, добра и зла, греха и воздаяния. По специфике сознания персонажей романа выделяются три основных типа выполняемых ими ролей: роли «нечистой силы», роли обывателей, роли представителей власти и «наиболее развитых и культурных людей». Носители различных ролей имеют неравноправный статус: «нечистая сила» как представитель метафизического мира по своим возможностям оказывается выше других участников коммуникации. В большинстве случаев все ситуации характеризуются напряженностью и эмоциональностью, что находит свое отражение в языке романа (наличие большого количества вопросительных и восклицательных предложений, эмоционально окрашенной лексики и фразеологии, полифония интонаций), а также сопутствующих невербальных средствах - мимике и жестах.

Ключевые слова

научный и религиозный дискурсы, художественно-литературный дискурс, дискурсно-коммуникативные столкновения, коммуникативные роли, характер коммуникативных ситуаций, вербальные и невербальные средства.
\end{abstract}

1 Введение. В коммуникативном пространстве общества, его семиосфере, наука, религия и художественная литература занимают различные зоны. Две полярные области - это наука и религия, которые, с точки зрения дискурсологии, различаются базовыми целями своих дискурсов, набором их конститутивных и различительных признаков, ментальных установок и предубеждений, своеобразием языковых средств. Содержательные, смысловые противоречия между этими двумя дискурсами - научным и религиозным иногда оказываются настолько больши́ми, что приводят к драматическим (а иногда и трагическим) коллизиям в конкретных исторических условиях. Вспомним, например, сожжение инквизицией Н. Коперника за его учение о гелиоцентрическом устройстве мира.

Существенна избранная в дискуссии модель диалога. Риторический диалог предполагает оппозицию и стремление к преимуществу и победе мнения каждой из независимых сторон (Walton, 1993). В настоящее время диалог связывается с представлением об интертекстуальности и интердискурсности (Dijk, 1997). Приоритет отдан межличностной функции диалога, которая реализуется в ролевых отношениях и эмоциональности (Sullivan, 1995). Идеалом становится сотрудничество, создание общего смысла, то есть кооперативный диалог (Todorov, 1984). В дискурсивном ракурсе наблюдается расширение интерпретации диалога как формы существования языка. Такой подход включает теоретическое и теоретико-дидактическое рассмотрение (Gordon, 1996; Halliday, 1993; Ivanov, 1974; Jakubovska, 2014; Waldnerova, 2014). 
Одной из важнейших задач и науки, и религии является нахождение общих смыслов, создание коммуникативного пространства, в котором будут находить примирение истины науки и религии. Это понимали еще в древности, основав теорию двойственной истины, развитую затем в философии религии и призванную объединить и примирить две важнейшие эпистемы - веру и разум (Giruckij - Novruzov, 2013: 21 - 45).

Художественно-литературный дискурс в рассматриваемом коммуникативном ряду занимает срединную зону. В нем в той или иной форме могут находить отражение научный, религиозный и иные дискурсы в их связях, взаимодействии, столкновениях в конкретных коммуникативных ситуациях, а также в мировоззрении, поведении различных литературных персонажей, диалогичность которых моделирует автор (Busch, 1990; Holquist, 1983; Perlina, 1984; Todorov, 1984 и др.). Ярким примером этого служит роман М.А. Булгакова «Мастер и Маргарита», сюжетная линия которого движется, как известно, историей четырехсуточных гастролей той трансцендентной силы, «что вечно хочет зла и вечно совершает благо».

1.1 Главная особенность коммуникативного пространства романа «Мастер и Маргарита» характеризуется оппозитивным столкновением двух начал - физического и метафизического, добра и зла, греха и воздаяния, веры и атеизма, земного и небесного. Воланд и его окружение («нечистая сила») являются, по сути, представителями метафизического мира, носителями той трансцендентной силы, которая находится за пределами обыденного и научного сознания и понимания. Общение с этой силой выходит за рамки привычной коммуникации людей, поскольку Воланд и его свита, с одной стороны, являются реальными коммуникантами, а с другой - обладают сверхъестественными способностями, которые и проявляют в конкретных коммуникативных ситуациях. Особенностью таких ситуаций служит то, что в них чаще всего сталкивается метафизическое сознание с обыденным и/или научным сознанием.

Воланд, булгаковский Князь Тьмы, со своей свитой далеки от носителей религиозности в каноническом смысле этого слова, как, впрочем, далеки и от носителей подлинной научности (в дискурсивном смысле) сталкивающиеся с ними герои романа. Это, скорее, столкновение мистического начала, признание которого (в том числе и его темной стороны) является обязательной частью религиозного дискурса, с атеистическим (якобы научным) мировоззрением, не признающим ни Бога, ни черта. Результатом столкновения этих двух начал, наслоившихся на повседневную московскую реальность 20 30-х годов XX века, явились произошедшие в романе драматические и трагические события. Они вызвали у многих персонажей романа религиозный ужас перед совершившимся и грядущим возмездием. Рассмотрим некоторые дискурсно-коммуникативные особенности этих столкновений на конкретных примерах, взятых из булгаковского романа.

\subsection{1 Столкновение религиозного переживания с атеистическим} рассудком. Религиозное переживание является одним из признаков религиозного дискурса. В научной литературе выделяют различные типы религиозных переживаний - откровение, мистические, харизматические, индуцированные переживания и др. (Tompson, 2001: 17 - 44). Причем охватывать они могут как верующих, так и неверующих.

Описано множество различных состояний, возникающих у человека в момент таких переживаний. Столкновение с трансцендентным, мистическим началом может вызвать у него непроизвольный танец, вздымание волос на теле дыбом, может заставить его громко кричать или кататься по полу, петь или 
смеяться и др. (Tompson, 2001, 37 - 38). Вспомним, кстати, булгаковский хор в филиале городских зрелищных комиссий, вынужденный против своей воли исполнять Славное море священный Байкал ...

Общей чертой наиболее сильных религиозных переживаний, таких как откровение и мистицизм, выступает их неожиданный и разрушительный для личности характер. Как правило, эти виды религиозных переживаний влекут за собой кардинальные изменения в жизни тех, кто их испытал. Конечно, не все религиозные переживания бывают столь драматичными, однако подлинность столкновения с мистическим, трансцендентным подтверждается тем, что в момент столкновения возникает чувство глубокой тревоги, захватывающее всего человека. Пророк Мухаммед, например, утверждал, что полученное им свыше приказание «возвестить» Коран ужаснуло его (Tompson, 2001: 24 - 25). Ужасает встреча с мистическим началом, вплоть до потери рассудка, и многих героев романа М.А. Булгакова.

Уже на первых страницах романа необъяснимый ужас внезапно испытывает Берлиоз, не понимая, что он входит в контакт с метафизическим началом: «Тут приключилась вторая странность, касающаяся одного Берлиоза. Он внезапно перестал икать, сердие его стукнуло и на мгновение куда-то провалилось, потом вернулось, но с тупой иглой, засевшей в нем. Кроме того, Берлиоза охватил необоснованный, но столь сильный страх, что ему захотелось тотчас же бежать с Патриариих без оглядки. Берлиоз тоскливо оглянулся, не понимая, что его напугало» (Tut prikl'učilas vtoraja strannost, kasajuščajasja odnogo Berlioza. On vnezapno perestal ikat', serdce jego stuknulo i na mgnovenije kuda-to provalilos, potom vernulos, no stupoj igloj, zasevšej v ňom. Krome togo Berlioza ochvatil neobosnovannyj, no stol' sil'nyj strach, čto jemu zachotelos totčas že bežat's Patriaršich bez ogl'adki. Berlioz tosklivo ogl'anulsja, ne ponimaja, čto jego napugalo; Bulgakov, 1982: 11).

Известно, что в случаях религиозных переживаний их источник находится вне метакоммуниканта, и в большинстве случаев не видим, но воздействие происходит изнутри. Берлиоз вначале также ищет источник своего сильного страха в пространстве вокруг себя, но в первые мгновения тот никак себя не обнаруживает, поэтому охранительный рассудок переводит все в привычные рамки: жара, переутомился. Однако метакоммуникативное событие продолжает развиваться. Ужас не верящего в потусторонние явления Берлиоза усиливается, когда перед ним из знойного воздуха неожиданно соткался «прозрачный гражданин престранного вида»: «Тут ужас до того овладел Берлиозом, что он закрыл глаза» (Tut užas do togo ovladel Berliozom, čto on zakryl glaza; Bulgakov, 1982: 11). Коварство потусторонности, уже определившей его судьбу (Аннушка уже купила подсолнечное масло), в дальнейшем общении с Берлиозом проявилось в том, что когда он открыл глаза, то увидел, «что все кончилось, марево растворилось, клетчатый исчез, а заодно и тупая игла выскочила из сердиа. - Фу ты черт! - воскликнул редактор, - ты знаешь, Иван, y меня сейчас едва удар от жары не сделался! Даже что-то вроде галлюиинации было, - он попытался усмехнуться, но в глазах его еще прыгала тревога, и руки дрожали» (с̌to vsjo končilos, marevo rastvorilos, kletčatyj isčez, a zaodno i tupaja igla vyskočila iz serdca. - Fu ty čort! - voskliknul redaktor, - ty znaješ, Ivan, u meňa sejčas jedva udar ot žary ne sdelalsja! Daže čto-to vrode gall'ucinacii bylo, - on popytalsja usmechnut'sja, no v glazach jego ješčo prygala trevoga, i ruki drožali; Bulgakov, 1982: 11). Метакоммуникативное событие состоялось, завершившись вполне благополучно для Берлиоза. В силу своей кратковременности оно никоим образом не поколебало его атеистических 
убеждений, позволив вести обстоятельный разговор с Иваном Бездомным о том, что фигура Иисуса Христа - это миф.

Еще одной характерной чертой мистического переживания является присутствие в этом событии внешней странности, непривычности обстоятельств происходящего. В этой связи можно вспомнить Моисея перед пылающим кустом, Христа в пустыне, Мухаммеда в пещере (Tompson, 2001: 23). При этом даже самые обычные обстоятельства, которые могут иметь рациональное объяснение, у метакоммуниканта получают тревожный и странный смысл. Согласно роману, первая странность происходящего на Патриарших прудах заключалась как раз в таких внешних обстоятельствах. Во всей аллее, несмотря на страшную жару, не оказалось ни одного человека: «никто не пришел под липь, никто не сел на скамейку, пуста была аллея» (nikto ne prišol pod lipy, nikto ne sel na skamejku, pusta byla alleja).

В нашем случае была еще одна внешняя странность, роковым образом определившая судьбу и Берлиоза, и поэта Бездомного. Этой мучительно неуловимой уже в определении национальности странностью (немец? англичанин? франщуз? поляк?) оказалась для них материализовавшаяся в образе Воланда потусторонняя сила. Беседа с ним Берлиоза и Бездомного вызывает у тех постоянное чувство то меньшей, то большей тревоги и странности. Избавление от беспокойства, вызываемого личностью Воланда и его речами, происходит самым естественным образом. Поэт Бездомный переводит все с помощью атеистического рассудка в привычные рамки повседневной жизни: «Вот что, Миша, - зашептал поэт, оттащив Берлиоза в сторону, - он никакой не интурист, а шипон. Это русский эмигрант, перебравшийся $к$ нам. Спрашивай у него документы, а то уйдет...Tы думаешь? - встревоженно шепнул Берлиоз, а сам подумал: «А ведь он прав!» (Vot čto, Miša, - zašeptal poet, ottaščiv Berlioza v storonu, - on nikakoj ne inturist, a špion. Eto russkij emigrant, perebravšijsja k nam. Sprašivaj u nego dokumenty, a to ujd'ot...-Ty dumaješ? vstrevoženno šepnul Berlioz, a sam podumal: «A ved' on prav!»; Bulgakov, 1982: 18). Однако же когда выяснилось, что иностранец никакой не шпион, то невозможность совместить с рассудком возникающие странности приводит развитие коммуникативной ситуации, в которой эти странности сталкиваются, к логическому финалу: "Вот тебе все и объяснилось! - подумал Берлиоз в смятении, - приехал сумасшедший немец или только что спятил на Патриарших. Вот так история!». Да, действительно, объяснилось все: $и$ страннейший завтрак у покойного философа Канта, и дурачкие речи про подсолнечное масло и Аннушку, и предсказание о том, что голова будет отрублена, и все прочее - профессор был сумасшедший» (Vot tebe vsjo $i$ objasnilos! - podumal Berlioz v smjatenii, - prijechal sumaš̌edšij nemec ili tol'ko čto spjatil na Patriaršich. Vot tak istorija!». Da, dejstvitel’no, objasňalos vsjo: i strannejšij zavtrak u pokojnogo filosofa Kanta, i durackije reči pro podsolnečnoje maslo i Annušku, i predskazanije o tom, čto golova budet otrublena, i vsjo pročeje profesor byl sumaš̌eďi ij; Bulgakov, 1982: 39).

\subsection{2. Столкновение измененного религиозным переживанием} сознания с повседневной реальностью. Религиозные переживания могут оказывать сильнейшее воздействие на участников, но остальным людям будут казаться чем-то совершенно безумным. Столкнувшись с метафизической реальностью, человек может некоторое время находиться в измененном состоянии сознания, кажущимся окружающим безумием (Tompson, 2001: 27). В этот период человек выходит из-под власти естественных механизмов рационального контроля, разрушаются все обычные барьеры между собственной личностью и внешним миром, переживаемое обладает такой силой, что требует немедленной реализации, невзирая на социальные условности. При 
этом метакоммуникат физически достаточно хорошо ориентируется в реальном мире.

В таком состоянии в романе оказывается поэт Иван Бездомный, увидев, как отрезанная трамваем голова Берлиоза подскакивала на мостовой: «Om этого он до того обезумел, что, упавши на скамью, укусил себя за руку до крови» (Ot etogo on do togo obezumel, čto, upavši na skamju, ukusil sebja za ruku do krovi; Bulgakov, 1982: 42). С этого момента он впадает в состояние, которое в философии религии называют развивающимся религиозным переживанием. Две мысли оказываются доминирующими в сознании поэта, и обе связаны с Воландом: «Первая: Он отнюдь не сумасшедший! Все это глупости!», и вторая: «Уж не подстроил ли он все это сам?!» («Pervaja: On otñud” ne sumašedšij! Vsjo eto gluposti!», i vtoraja: «Už ne podstroil li on vsjo eto sam?!»; Bulgakov, 1982: 43). Эти мысли определяют все дальнейшее поведение Ивана Николаевича, сжато сформулированное его болезненным сознанием: «- Э нет! Это мы узнаем!» («E net! Eto my uznajem!»; Bulgakov, 1982: 43). Сознание Бездомного обретает болезненную двойственность, которую он, пройдя через цепь совершаемых им странных (с точки зрения окружающих, но не самого поэта) поступков, преодолевает в психиатрической клинике с помощью логики профессора Стравинского. Тот переводит весь этот метафизический вздор, случившийся с Иваном Николаевичем, на обычный житейский язык: «Теперь я скажу вам, что, собственно, с вами произошло. Вчера кто-то вас сильно напугал и расстроил рассказом про Понтия Пилата и прочими вещами. И вот вы, нанервничавшийся, издерганный человек, пошли по городу, рассказывая про Понтия Пилата. Совершенно естественно, что вас принимают за сумасшедмего. Ваме спасение сейчас только в одном - в полном покое. И вам непременно нужно ocmamься здесь» (Teper ja skažu vam, čto, sobstvenno, s vami proizošlo. Včera ktoto vas sil’no napugal i rasstroil rasskazom pro Pontija Pilata i pročimi veščami. I vot vy, nanervničavšijsja, izd’organnyj čelovek, pošli po gorodu, rasskazyvaja pro Pontija Pilata. Soveršenno jestestvenno, čto vas vse prinimajut za sumasšedšego. Vaše spasenije sejčas tolko v odnom - v polnom pokoje. I vam nepremenno nužno ostat'sja zdes; Bulgakov, 1982: 78).

Но сила пережитого мистического состояния обычно такова, что даже находящаяся в отчаянном состоянии личность не поддается убеждающему воздействию рациональной оценки. То же происходит и с Иваном Бездомным: «- Но его необходимо поймать! - уже моляще воскликнул Иван» («- No јеgо neobchodimo pojmat!! - uže mol’ašče voskliknul Ivan»; Bulgakov, 1982: 78). Однако не зря поэт думал о Стравинском, что тот «положительно умен». Бездомному, как известно из романа, не удается выиграть поединок с ним, поскольку профессор хорошо знал, что мистические переживания, резко отличаясь от обыденного опыта, трудно поддаются описанию, а уж тем более переводу на язык официальных заявлений, язык деловых бумаг. Поэтому он совершенно спокойно соглашается с поэтом, что Воланда нужно поймать, и коварно предлагает Ивану Николаевичу изложить все в виде официального заявления: «- Хорошо-с, но самому-то зачем же бегать? Изложите на бумаге все ваши подозрения и обвинения против этого человека. Ничего нет проще, как переслать ваше заявление куда следует, и если, как вы полагаете, мы имеем дело с преступником, все это выяснится очень скоро» («- Chorošo-s, по samomu-to začem že begat’? Izložite na bumage vse vaši podozrenija i obvinenija protiv etogo čeloveka. Ničego net prošče, kak poslat'vaše zajavlenije kuda sledujet, $i$ esli, kak vy polagajete, my imejem delo s prestupnikom, vsjo eto vyjasnitsja očen̆ skoro»; Bulgakov, 1982: 78). Как известно из романа, попытки Бездомного сочинить заявление насчет страшного консультанта не привели ни к чему. 
2.1 Особенности коммуникативной организации романа находят свое отражение и в ролях, выполняемых его персонажами. По специфике сознания в ведущем сюжете романа можно выделить три основных типа ролей, в которых выступают его персонажи.

2.1.1 Роли «нечистой силы». Их играют Воланд и его свита, выступающие носителями трансцендентного, метафизического сознания. Оно находится за порогом адекватного понимания обыденным и научным сознанием, стоит выше их и в силу этого ставит в неравное положение общение с ним носителей другого сознания. Суть этого неравенства заключается, с одной стороны, в том, что «нечистой силе» открыта та истина, которая недоступна обычным людям. С другой стороны, Воланд и его свита обладают запредельными возможностями в реальном, физическом мире. Они могут свободно перемещаться в пространстве и времени, перебрасывать человека из одной точки пространства в другую, проделывать различные «фокусы» с человеческим телом, манипулировать сознанием людей и подчинять их волю, вынуждая тех совершать странные поступки и т.д. и т.п. В силу этого «нечистая сила» выводит коммуникацию за границы привычного физического мира, расширяя ее до метафизических пределов.

2.1.2 Роли обывателей. Они являются в романе носителями, прежде всего, обыденного сознания. Представленный в романе обыватель 20 - 30 гг. $\mathrm{XX}$ века (в основном московский) склонен верить власти и принимать ее объяснение происходящих в романе событий. В то же время он верит и распространяемым слухам, допускает возможность проделок «нечистой силы», тем более что слухи базируются на фактах, отмахнуться от которых без объяснений никак нельзя. Эта двойственность сознания обывателя с его одновременной верой в «нечистую силу» и ее возможности и верой в официальные, «научные» объяснения событий ярко демонстрируется в эпилоге романа. С одной стороны, обыватели пытаются сами бороться с «нечистой силой», истребляя черных котов, а с другой - считают, что это прерогатива власти (уж та разберется!), доставляя котов, иногда в сильно изуродованном виде, в отделения милиции в разных городах.

Особо в романе стоят обыватели, которые входили в непосредственный контакт с «нечистой силой». Большинство из них становятся «жертвами» Воланда и его свиты. Фактически здесь возникает оппозиция ролей, которую условно можно назвать «палачи и жертвы», несмотря на то, что возмездие, настигающее «жертв», в большинстве случаев справедливое (воздается по делам их!). Метафизический статус «нечистой силы» предопределяет еще одну особенность возникающих коммуникативных ситуаций. «Нечистая сила» практически всегда появляется перед обывателем неожиданно, хотя и пытается потом дать рациональное объяснение своему появлению в том или ином месте. Несмотря на такие попытки, обыватель ощущает как алогичность ее появления, так и странности, нестыковки происходящего, которые вызывают в нем чувство тревоги, дискомфорта.

2.1.3 Роли представителей власти и «наиболее развитых и культурных людей» (M. Bulgakov). Это носители официальной, научной точки зрения на происходящие в романе события. «Культурные» люди, как и представители власти, никакого участия в рассказах о «нечистой силе» не принимают, смеются над ними, и пытаются рассказчиков образумить. Носителями научного мировоззрения выступают уже на первых страницах романа «культурные» литераторы Берлиоз и Бездомный, пытающиеся образумить Воланда с его странными речами на Патриарших прудах и одновременно продемонстрировать ему превосходство научного, атеистического мировоззрения. Такую же попытку предпринимает и 
председатель акустической комиссии московских театров Аркадий Аполлонович Семплеяров, призывающий в Варьете Фагота незамедлительно разоблачить перед зрителями технику его фокусов и возвратить конферансье на сцену. В эпилоге романа точка зрения «наиболее развитых и культурных людей» совпадает с официальной: работала шайка гипнотизеров и чревовещателей. Естественно, что рациональное, логическое объяснение происходящим в Москве событиям, связанным с «нечистой силой», ищет следствие. При этом в окончательной «научной» трактовке произошедших в Москве событий факты, не поддающиеся объяснению, подтасовываются или исчезают, как, например, не обнаружилось в делах ни одной копии телеграмм, которые угрозыск Ялты слал в Москву насчет Степы Лиходеева.

2.1.4 Особая роль в контактах с «нечистой силой» принадлежит в романе Маргарите. Уже после первого общения в Александровском саду с Азазелло она готова сотрудничать с этой силой, лишь бы получить возможность встречи с Мастером: Нет, погодите... я знаю, на что иду. Но иду на все из-за него, потому что ни на что в мире больше надежды у меня нет. Но я хочу вам сказать, что, если вы меня погубите, вам будет стылно! Да, стылно! Я погибаю из-за любви! - и, стукнув себя в грудь, Маргарита глянула на солнще (Net, pogodite... ja znaju, na čto idu. No idu na vsjo iz-za nego, potomu čto ni na čto $v$ mire bol’še nadeždy u meňa net. No ja choču vam skazat', čto, jesli vy meňa pogubite, vam budet stydno! Da, stydno! Ja pogibaju iz-za l'ubvi! - $i$, stuknuv sebja v grud, Margarita glanula na solnce; Bulgakov, 1982: 186). В этом эмоциональном монологе и объяснение своего решения на встречу «с иностранцем», и страх быть обманутой, и надежда.

3.1 Характер коммуникативных ситуаций. Возникающие во время контакта с «нечистой силой» коммуникативные ситуации различны. Эти различия обусловливаются социальным положением персонажей, характером коммуникативного события и другими факторами. Однако почти во всех случаях каждая ситуация представлена неравноправным статусом коммуникантов. Обыватель по своему коммуникативному статусу всегда ниже, чем представитель «нечистой силы», поскольку последний может свободно манипулировать сознанием обывателя, знает о нем все, и может проделать с ним при желании все, что хочет.

Еще одной приметной структурной особенностью ряда коммуникативных ситуаций при общении с «нечистой силой» является их контрастность. Как правило, начало коммуникативного события развивается по принципу кооперации, а в конце неожиданным для коммуниканта образом заканчивается конфронтацией. Один из ярких примеров - выдворение Степы Лиходеева из квартиры № 50. Начало события - в квартире невесть откуда появляется Воланд. При этом он сама учтивость и любезность. Воланд улыбчиво рассыпается перед Степой, «вникает» в его тяжелое похмельное состояние, предлагает водку и закуски как единственное средство облегчить это состояние, предупредительно растолковывает Степе все странности происходящего.

В художественном дискурсе эстетическое и лингвистическое тесно связаны (см. подробнее: Ляшук, 2013 а). Каждый художественный текст, как и любой письменный текст русской культуры «podvergajetsja intuitivnoj identifikacii nositel'ami russkogo jazykovogo soznanija», происходит его «иznavanije i ocenka kak svojego po slovesnomu vyraženiju» (Ляшук, 2013 b: 68). Все литературные персонажи романа ведут диалог в русской языковой традиции, узнаваемыми языковыми средствами, поэтому естественно, что желание Воланда быть вежливым, предупредительным и заботливым отражается в его 
интонациях, лексике, мимике: симпатичнейший Степан Богданович (simpatičnejšij Stepan Bogdanovič); дорогой Степан Богданович (dorogoj Stepan Bogdanovič); дражайший Степан Богданович, вот и я! (dražajšij Stepan Bogdanovič, vot i ja!); ни слова больше! (ni slova bol'še!); с удовольствием! (s udovol'stvijem!); благодарствуйте (blagodarstvujte); я надеюсь (ja nadejus); о, конечно, конечно! (o, konečno, konес̌no!); о, какой вздор! (o, kakoj vzdor!); пожалуйста, пожалуйста (роžalujsta, požalujsta); дружелюбно усмехнулся (druželubno usmechnulsja); неизвестный ульбнулся (neizvestnyj ulybnulsja); пронииательно ульљаясь (pronicatel'no ulybajas) и др. Степа следует за его волей и логикой, стараясь, насколько это возможно в его состоянии, также быть любезным и учтивым, и в рамках этой парадигмы разрешить все возникающие в его мозгу нестыковки происходящего.

Ситуация резко меняется, когда в спальне неожиданно появляется компания, среди которой оказывается «жутких размеров черный кот со стопкой водки в одной лапе и вилкой, на которую он успел поддеть маринованный гриб, в другой» (žutkich razmerov čornyj kot so stopkoj vodki v odnoj lape $i$ vilkoj, na kotoruju on uspel poddet' marinovannyj grib v drugoj; Булгаков, 1982: 70). Воланд объявляет, что квартира нужна ему и свите, а Степа здесь лишний. Такой неожиданный «кукиш» от любезного Воланда уже сам по себе способен привести в смятение. Но когда Степа видит, что кот выпивает водки, то его рука «ползет по притолоке вниз» (polzjot po pritoloke vniz). Свита меняет характер общения со Степой с учтиво любезного, продемонстрированного Воландом, на «разоблачительный» с соответствующим набором языковых средств: они в последнее время жутко свинячат (oni v posledneje vremja žutko sviňačat); пьянствуют, вступают в связи с женщинами (pjanstvujut, vstupajut v svjazi s ženščinami); ни черта не делают (ni čerta ne delajut); ничего не смыслят в том, что им поручено (ničego ne smysl'at v tom, čto im poručeno); машину гоняют казенную (таšinu gойајиt kazjonпији); начальству втирают очки (načal'stvu vtirajut očki); он такой же директор, как я архиерей (on takoj-že direktor, kak ja archijerej); козлиным голосом запел длинный клетчатый (kozlinym golosom zapel kletčatyj); наябедничал и кот (najabedničal $i$ kot); прогнусавил рыжий (prognusavil ryžij); вдруг рявкнул кот (vdrug rjavknul kot) и др. В итоге, как известно, Лиходеев оказывается в Ялте на берегу моря.

«Разоблачение» может быть отложенным по времени и исполнителям, то есть произойти не в момент контакта с «нечистой силой», а позднее, и произведено другими людьми, чаще всего представителями «карающих» органов. Так, например, происходит с председателем жилищного товарищества дома № 302-бис по Садовой улице Никанором Ивановичем Босым, который хлопотами Коровьева оказывается уличенным «официальными лицами» в хранении валюты в сортире.

3.2 Метафизический статус свиты Воланда, знание ими всего о том или ином конкретном человеке обусловливает то, что в большинстве случаев ее представители в общении с людьми бывают до приторности предупредительны и любезны. Зачастую они ёрничают, когда тот или иной коммуникант пытается подать себя как важную и значительную официальную или просто порядочную персону. Тут взгляды «нечистой силы» и того или иного коммуниканта на важность, значительность, официальность и порядочность расходятся, как, например у Босого и Коровьева: - Эх, Никанор Иванович! - задушевно воскликнул неизвестный. - Что такое официальное лицо или неофициальное? Все это зависит от того, с какой точки зрения смотреть на предмет, все это, Никанор Иванович, условно и зыбко. Сегодня я неофициальное лицо, а завтра, глядишь, официальное! А бывает и наоборот, Никанор Иванович. И еще как бываem! (-Ech, Nikanor Ivanovič! - zaduševno voskliknul neizvestnyj. - Čto takoje 85

XLinguae Journal, Volume 8 Issue 4, October 2015, ISSN 1337-8384 
oficialnoje lico ili neoficialnoje? Vsjo eto zavisit ot togo, skakoj točki zrenija smotrjet' na predmet, vcjo eto, Nikanor Ivanovič, uslovno i zybko. Segodňa ja neoficialnoje lico, a zavtra, gl'adiš, oficialnoje! A byvajet $i$ naoborot, Nikanor Ivanovič. I ješčo kak byvajet!; Bulgakov, 1982: 80). Учтивость же и любезность представителям «нечистой силы» нужна для того, чтобы «ввести в заблуждение» противника и легчайшим образом добиться нужного результата.

Так, например, развивается ситуация общения Коровьева с председателем жилищного товарищества Босым, когда тот посещает квартиру № 50. Естественно, что Босой в разговоре с Коровьевым, который неожиданно для Никанора Ивановича почему-то оказывается в опечатанном кабинете, позиционирует себя как официальное лицо. Соответственно ситуации Босой задает резонные вопросы: Я извиняюсь, - заговорил он подозрительно, - вы кто такой будете? Bы - лицо официиальное? (Ja izviňajus, - zagovoril on podozritel'no, - vy kto takoj budete? Vy - lico oficial'noje?; Bulgakov, 1982: 80). После задушевного изложения Коровьевым своих взглядов на официальность и неофициальность Никанор Иванович приходит к выводу, что "разглагольствующий перед ним гражданин - лицо именно неофищиальное, а, пожалуй, и праздное» (razglagol'stvujuščij pered nim graždanin - lico imjenno neoficial'noje, a, požaluj, i prazdnoje). Как лицо официальное, он суровеет: Да кто вы такой будете? Как ваша фамилия? - все суровее спрашивал председатель и даже стал наступать на неизвестного (Da kto vy takoj budete? Kak vaša familija? - vsjo suroveje sprašival predsedatel' i daže stal nastupat' na neizvestnogo; Булгаков, 1982: 80). Коровьев не смущается суровостью председателя, называет ему свою фамилию, оставаясь все таким же «задушевным» и любезным: Да не хотите ли закусить, Никанор Иванович? Без иеремоний? A? (Da ne chotite li zakusit, Nikanor Ivanovič? Bez ceremonij? A?; Bulgakov, 1982: 80). Такое предложение неофициального и даже праздного лица лицу официальному приводит председателя в негодование: Я извиняюсь, - уже негодуя, заговорил Никанор Иванович, - какие тут закуски! - На половине покойника сидеть не разрешается! Вы что здесь делаете? (Ja izvin̆ajus, - uže negoduja, zagovoril Nikanor Ivanovič, - kakije tut zakuski! - Na polovine pokojnika sidet' ne razrešajetsja! Vy čto zdes delajete?). В ответ на грубость Босого Коровьев начинает ёрничать: Да вы присаживайтесь, Никанор Иванович, - нисколько не теряясь, орал гражданин и начал юлить, предлагая председателю кресло.

Совершенно освирепев, Никанор Иванович отверг кресло и завопил: - Да кто вы такой?

- Я, изволите ли видеть, состою переводчиком при особе иностранца, имеюшего резидениию в этой квартире, - отрекомендовался назвавший себя Коровьевым и щелкнул каблуком рыжего нечищенного ботинка (Da vy prisaživajtes, Nikanor Ivanovič, - niskolko ne terjajas, oral graždanin i načal julit, predlagaja predsedatel'u kreslo.

Soveršenno osvirepev, Nikanor Ivanovič otverg kreslo i zavopil:

- Da kto vy takoj?

- Ja, izvolite li videt', sostoju perevodčikom pri osobe inostranca, imejuščego rezidenciju vetoj kvartire, - otrekomendovalsja nazvavšij sebja Korovjevym i ščolknuk kablukom ryžego nečiščennogo botinka; Bulgakov, 1982: 80 $81)$.

Упоминание об иностранце в социально-политической ситуации того времени переводит общение в другую фазу. Напряжение спадает, требуются объяснения (не наломать бы дров!), которые охотно дает Коровьев. С его стороны тональность общения остается не только приторно любезной, но и становится дружески доверительной (мы-то с вами знаем, кто такие 
иностранцы!), что проявляется в использовании им соответствующей лексики и невербальных средств: Говорю вам, капризен, как черт знает что! - зашептал Коровьев, - ну не желает! Не любит он гостиниц! Вот они где у меня сидят, эти интуристы!! - интимно пожаловался Коровьев, тыча пальием в свою жилистую шею, - верите ли, всю душу вымотали! Приедет... и или нашпионит, как последний сукин сын, или же капризами все нервы вымотает: и то ему не так, и это не так!.. А вашему товариществу, Никанор Иванович, полнейшая выгода и очевидный профит. А за деньгами он не постоит, - Коровьев оглянулся, а затем шепнул на ухо председателю: - миллионер! (Govorju vam, kaprizen, kak čort znajet čto! - zašeptal Korovjev, - nu ne želajet! Ne l’ubit on gostinic! Vot oni gde u meňa sid'at, eti inturisty! - intimno požalovalsja Korovjev, tyča pal'cem v svoju žilistuju šeju, - verite li, vsju dušu vymotali! Prijedet... i ili našpionit, kak poslednij sukin syn, ili že kaprizami vse nervy vymotajet: $i$ to jemu ne tak, i eto ne tak!.. A vašemu tovariščestvu, Nikanor Ivanovič, polnejšaja vygoda $i$ očevidnyj profit. A za deňgami on ne postoit, - Korovjev ogl'anulsja, a zatem šepnul na ucho predsedatel'u: - millioner!; Bulgakov, 1982: 82).

«Разоблачение» официального лица Коровьев не производит. Но по его наводке таковое производят уже несколько позднее другие официальные лица с соответствующими «документиками», обвинив Босого в спекуляции валютой.

Характерной чертой диалогов «нечистой силы» с обывателями является их эмоциональный характер, который задают представители «нечистой силы», демонстрируя повышенную учтивость, любезность, предупредительность и заботливость. Отсюда большое количество восклицательных предложений в таких диалогах. Даже достаточно сдержанный Воланд в рассмотренном выше диалоге со Степой Лиходеевым демонстрирует изрядную эмоциональность.

Эмоциональность диалогов отражается в лексике и фразеологии персонажей: симпатичнейший, дорогой, дражайший, дорогой наш друг, сволочь, склочник, приспособленец, подхалим, втирают очки, не лезет в голову, черт знает что (simpatičnejšij, dorogoj, dažajšij, dorogoj naš drug, svoloč, skločnik, prisposoblenec, podchalim, vtirajut očki, ne lezet $v$ golovu, čort znajte čto) и др., сопутствующих невербальных средствах, фиксируемых в авторской речи: остановился в изумлении, вздрогнул, стал наступать, щзелнул каблуком, открыл рот, тупо глядя, замахал руками, тыча пальцем, воровски подмигнул, растерянно ухмыльнувшись, лихо выписал, метнул взгляд, густо покраснел, стал отпихивать, прошептал и оглянулся (ostanovilsja v izumlenii, vzdrognul, stal nastupat', ščolknul kablukom, otkryl rot, tupo gl'ad'a, zamachal rukami, tyča pal'cem, vorovski podmigmul, rasterjanno uchmyl'nuvšis, licho vypisal, metnul vzgl'ad, gusto pokrasnel, stal otpichivat', prošeptal i ogl'anulsja) и др.

3.3 Характер общения «нечистой силы» с Маргаритой иной, чем с другими обывателями. Он определяется тем, что Воланд хочет сделать ее королевой своего бала. Поэтому обходительность и учтивость, проявляемая «нечистой силой» в отношениях с ней, не притворная, а естественная, настоящая. Тем не менее, уже первое общение Маргариты с представителем «нечистой силы» достаточно эмоциональное. Об этом свидетельствуют количественные подсчеты типов предложений, представленные в таблице 1. 
Таблица 1. Подсчет типов предложений

\begin{tabular}{|l|c|c|c|}
\hline \multirow{2}{*}{ Персонаж } & \multicolumn{3}{|c|}{ Типы предложений } \\
\cline { 2 - 4 } & $\begin{array}{l}\text { Повествовател } \\
\text { ьные }\end{array}$ & $\begin{array}{l}\text { Восклицательны } \\
\text { e }\end{array}$ & $\begin{array}{l}\text { Вопросительн } \\
\text { ые }\end{array}$ \\
\hline Маргарита & 24 & 12 & 26 \\
Азазелло & 45 & 16 & 5 \\
\hline
\end{tabular}

Та эмоциональность, которую проявляет Азазелло при первой встрече с ней, вызывается, прежде всего, ее настороженным отношением к незнакомцу. Азазелло в ответ пытается убедить ее в искренности и честности своих намерений, что требует проявления определенных чувств. Трудность этой задачи, по мнению самого Азазелло, состоит в том, что Маргарита - женщина: Трудный народ эти женщины! Он засунул руки в карманы и далеко вперед вытянул ноги, - зачем, например, меня послали по этому делу? Пусть бы ездил Бегемот, он обаятельный... (Trudnyj narod eti ženščiny! On zasunul ruki v karmany i daleko vperjod vyt'anul nogi, - začem, naprimer, meňa poslali po etomu delu? Pust' by jezdil Begemot, on obajatel'nyj ...; Bulgakov, 1982: 82).

Эмоциональность Маргариты несколько иная, чем у Азазелло. Она связана с ее любовью к Мастеру. Боже!; Еду!; еду куда угодно!; вы поманили меня словами о нем!; Я погибаю из-за любви! (Воže!; Jedu!; jedu kuda ugodno!; vy pomanili men̆a slovami o ňom!; Ja pogibaju iz-za l'ubvi!) - вот основная эмоциональная тема Маргариты в диалоге с Азазелло. Как видно из таблицы, преобладающими в общении с Азазелло у Маргариты являются вопросительные предложения. Это закономерно, поскольку, в отличие от Азазелло, который знает о Маргарите все, она ничего не знает о незнакомце и его намерениях. В ответ на ее вопросы Азазелло приходится в основном «повествовать»- отсюда преобладание повествовательных предложений в его речи. «Повествование» Маргариты представлено в основном в ее эмоциональных монологах о ее любви к Мастеру и готовности на все ради этой любви. Немногочисленные вопросы Азазелло связаны с уточнениями, касающимися согласия Маргариты на встречу «с иностранцем».

Общая «напряженность» анализируемой коммуникативной ситуации ярко демонстрируется разнообразием и «напряжением» речевых действий: спросила Маргарита (sprosila Margarita); объяснил рыжий (objasnil ryžij); развязно ответил рыжий (razvjazno otvetil ryžij); невольно спросила Маргарита (nevolno sprosila Margarita); вдруг воскликнула она (vdrug voskliknula ona); ответил рыжий (otvetil ryžij); голос ее стал глух (golos jejo stal such); сквозь зубы ответила Маргарита (skvoz zuby otvetila Margarita); сухо сказала Маргарита (sucho skazala Margarita); сказал таинственно (skazal tainstvenno); значительно сказал рыжий (značitelno skazal ryžij); обидевшись, воскликнул рыжий (obidevšis, voskliknul ryžij); проворчал рыжий и заговорил громче (provorčal ryžij i zagovoril gromče); моляще шепнула Mapzapuma (mol’ašč šepnula Margarita); неохотно отозвался Азазелло (пеосhotno otozvalsja Azazello); бормотала покорная теперь Маргарита (bormotala pokornaja teper Margarita); сказал сурово (skazal surovo); вкрадчиво спросила Маргарита (vkradčivo sprosila Margarita); покорно замолчала (pokorno zamolčala); сказала Маргарита задумчиво (skazala Margarita zadumčivo); в смятении воскликнула Маргарита (v smjatenii voskliknula Margarita); шепнул многозначительно (šepnul mnogoznačitel’no); с силой воскликнула Маргарита (s siloj voskliknula Margarita); заговорил иронически (zagovoril ironičeski); почти зашипел Азазелло (рос̆ti 
zašipel Azazello); в злобе зашипел Азазелло (v zlobe zašipel Azazello); вдруг заорал Азазелло (vdrug zaoral Azazello) и др.

Общий «напряженный» тон коммуникации создается и невербальными средствами, прежде всего, мимикой и жестами коммуникантов: вглядывваясь 8 неожиданного соседа (vgl'adyvajas v nеоžidannogo soseda); вдруг оскалилась (vdrug oskalilas); щурясь, спросила Mаргарита (ščrjas, sprosila Margarita); ульбаясь, заговорил рыжсий (ulybajas, zagovoril ryžij); побледнела $u$ отшатнулась (poblednela $i$ otšatnulas); оглянулся и сказал таинственно (ogl'anulsja i skazal tainstvenno); прищурив глаз (priščuriv glaz); поднимаясь, чтобы уходить (podnimajas, čtoby uchodit); обидевшись, проворчал в спину уходящей Маргарите (obidevšis, provorčal v spinu исhod’ǎšcej Margarite); побелев лицом (pobelev licom); глядел, пришурившись (gladel, priščcrivšis); страдальчески сморщилась (stradal'česki smorščilas); невесело усмехнулась (neveselo usmechnulas); рожу Азазелло перекосило смешком (гоžи Azazello perekosilo smeškom); криво и жалко улььбаясь (krivo i žalko ulybajas); гримасничая, отозвался Азазелло (grimasničaja, otozvalsja Azazello); Mapгapuma вспьхнула (Margarita vspychnula); стукнув себя в грудь (stuknuv sebja v grud'); вылупив глаза (vylupiv glaza) и др.

Заключение. Таким образом, особенности коммуникативного пространства романа «Мастер и Маргарита» определяются, прежде всего, тем, что в нем сталкиваются два мира - мир реальный, физический и мир потусторонний, метафизический. Это приводит к катастрофическим событиям в жизни ряда героев романа, испытавшим на себе воздействие потусторонней силы. «Нечистая сила», действующая в романе, определяет структурную особенность ролевой организации его коммуникативного пространства. Это, прежде всего, неравноправный статус носителей ролей: Воланд и его окружение как представители метафизического мира имеют более высокий статус, чем другие участники коммуникации.

Коммуникативные ситуации с участием «нечистой силы» отличаются, как правило, контрастностью своей содержательной структуры кооперативностью в начале и конфронтационностью в конце. Для обывателей общение с «нечистой силой» почти всегда имеет подтекст загадочности, странности, алогичности, различного рода нестыковок. При этом в большинстве случаев все ситуации характеризуются напряженностью и эмоциональностью, что находит свое отражение в языке романа, а также сопутствующих невербальных средствах.

\section{Bibliographic refernces}

BULGAKOV, M.A. 1982. Izbrannoje: Roman «Master i Margarita»; Rasskazy. Moskva: Chudozhestvennaja literatura.

BUSCH, R. 1990. Bakhtin's „Problemy tvorchestva Dostojevskogo“ and V.V.Vinogradov's „O khudozhestvennoj proze“ - A Dialog Relationship. Social Discourse. Vol. 3. Nr. 1-2, pp. 311-324.

DIJK, T.A. VAN. 1997. Discourse as Structure and Process. Discourse Studies: A Multidisciplinary Introduction. London, Thousand Oaks, New Delhi: SAGE Publications. Vol. 1, pp. 63-111.

GIRUCKIJ, A.A. - NOVRUZOV, R.M. 2013. Nauka i religija. Moskva: FLINTA, Nauka, 416 s. ISBN 978-5-9765-1057-9.

GORDON, J. 1996. Dialectic, Dialogue, and Transformation of the Self. Philosophy and Rhetoric. Vol. 29, Nr. 3, pp. 259-278. ISSN 0031-8213.

HALLIDAY, M.A.K. 1993. Towards a Language-based Theory of Learning. In: Linguistics and Education. Nr. 5, pp. 93-116. ISSN 0898-5898. 
HOLQUIST, M. 1983. Answering as Authoring: Mikhail Bakhtin's Translinguistics. Critical Inquiry. Vol. 10. Nr. 2, pp. 307-319. ISSN 0093-1896.

IVANOV, V.V. 1974. Growth of the Theoretical Framework of Modern Linguistics, Current Trends in Linguistics. Nr. 12, pp.835-861.

JAKUBOVSKA, V. 2014. Multikulturna komunikacia a jej specifika v literature. XLinguae. Europea Scientific Language Jornal. Volume 7, Issue 2, pp. 45-61. ISSB 1337-8384.

LIASHUK, V.M. 2013a. Lingvističeskij i estetičeskij diskurs: obščije i otličitel’nyje osobennosti. In: Aktualne otazky teorie diskurzu. Presov: FF PU, pp. 26-39. ISBN 978-80-555-0767-5.

LIASHUK, V.M. 2013в. Sinchronija i diachronija v sovremennych naučnych issledovanijach. In: ANTONAKOVA, D. - LIASHUK, V.M. - LIASHUK, K.G. Leksika v sinchronii i diachronii. Prešov: FF PU, s. 43-76. ISBN 978-80-555-1027-9. PERLINA, N. 1984. Bakhtin and Buber: Problems of Dialogic Imagination. Studies in Twentieth Century Literature. Nr. 9.1, pp. 13-28. ISSN 0145-7888.

PRINCE, G. 1990. Narrative Studies and Narrative Genres. In: Poetics Today. Nr. 11.2, p. 271-282. ISSN 0333-5372.

SULLIVAN, F.J. 1995. Critical Theory and Systemic Linguistics: Textualizing the Contact Zone. JAC. Nr.15 (3), pp. 411-434. ISSN 1867-5565.

TODOROV, Tz. 1984. Mikhail Bachtin: The Dialogical Principle. Minneapolis; London: Univ. of Minnesota Press. 132 p. ISBN 0-7190-1466-2.

TOMPSON, M. 2001. Filosofija religii. Moskva: FAIR-PRESS. ISBN 5-8183-0254-7. WALDNEROVA, J. 2014. Kulturna podmienenost komunikacneho spravania (kulturno-komunikacne korelacie). XLinguae. European Scientific Language Jornal. Volume 7, Issue 2, pp. 2-10. ISSB 1337-8384.

WALTON, D. 1993. Commitment, Types of Dialogue, and Fallacies. Informal Logic, XIV. Spring \&Fall. Nr. 2-3, pp. 93-103. ISSN 084-2577.

Words: 5782

Characters: 43378 (24, 1 standanrd pages)

Prof. Anatolij Antonovich Girutskij, DrSc.

Department of General and Russian Linguistics

Faculty of the Belarusian and Russian Philology

Belarussian State Pedagogical University named after Maxim Tank

Sovietskaya str., 18,220050, Minsk

Belarus

hirutski@mail.ru 